\title{
Assessment of Genetic Variation in Soybean (Glycine max) Accessions from International Gene Pools Using RAPD Markers: Comparison with the ISSR System
}

\author{
Kabwe Nkongolo ${ }^{1,2 *}$, Sarah Alamri ${ }^{1}$, Paul Michael ${ }^{2}$ \\ ${ }^{1}$ Department of Biology, Laurentian University, Sudbury, Ontario, Canada \\ ${ }^{2}$ Biomolecular Sciences Program, Laurentian University, Sudbury, Ontario, Canada \\ Email: *knkongolo@laurentian.ca
}

How to cite this paper: Nkongolo, K., Alamri, S. and Michael, P. (2020) Assessment of Genetic Variation in Soybean (Glycine max) Accessions from International Gene Pools Using RAPD Markers: Comparison with the ISSR System. American Journal of Plant Sciences, 11, 1414-1428

https://doi.org/10.4236/ajps.2020.119102

Received: August 14, 2020

Accepted: September 21, 2020

Published: September 24, 2020

Copyright $\odot 2020$ by author(s) and Scientific Research Publishing Inc. This work is licensed under the Creative Commons Attribution International License (CC BY 4.0).

http://creativecommons.org/licenses/by/4.0/

(c) (i) Open Access

\begin{abstract}
Soybean (Glycine max) is one of the most important crops in the world in terms of total production and usage. It is also among the least diverse species. The main objectives of the present study were to 1) assess the level of genetic variation among soybean (G. $\max$ ) accessions from different countries using Random Amplified Polymorphic DNA (RAPD) markers and 2) compare Inter Simple Sequence Repeats (ISSR) and RAPD marker systems in detecting polymorphic loci in soybeans ( $G$. $\max$ ). Genomic DNAs from 108 soybeans (G. $\max$ ) accessions from 11 different gene pools were analyzed using several ISSR and RAPD primers. The average level of polymorphic loci detected with the RAPD primers was $35 \%$. The soybean accessions from the China, Netherlands, and Canada gene pools were the least genetically variable with $25 \%$, $26 \%$, and $30 \%$ of polymorphic loci, respectively. Accessions from Hungary (43\%) and France (48\%) showed the highest level of polymorphism based on the RAPD analysis. Overall, RAPD data revealed that the accessions from different countries are closely related with $64 \%$ genetic distance values below 0.40 . The levels of polymorphic loci detected with the RAPD and ISSR marker systems were in general moderate and similar even if they target different regions of the genome. A combination of different marker systems that include RAPD/ISSR, microsatellites (SSR), and SNPs should provide the most accurate information on genetic variation of soybean ( $G$. max) accessions.
\end{abstract}

\section{Keywords}

Soybean, Glycine max, Genetic Variations, ISSR, RAPD, Molecular Markers 


\section{Introduction}

Soybean (Glycine max) is the most important grain legume in the world in terms of total production. Diversities in many crops such as soybean have been documented based on morphological and agronomical traits [1] [2]. Such characters are strongly influenced by environmental factors and the developmental stage of the plant. Since the early nineties, molecular markers have been developed as alternative methods and they are extremely effective in population genetics studies [3].

Protein or enzyme variation can be used to study genetic diversity of crop germplasm. However, the limited number of isozymes of proteins and enzymes can limit their usefulness. Polymorphic DNA markers can provide an ideal alternative method for evaluating genetic diversity in soybean germplasm [4] [5]. Soybean Restriction Fragment Length Polymorphism (RFLP) markers were first introduced in the late 1980s [4] [5] [6] [7]. Maughan et al. [8] evaluated 23 G. max and $G$. soja accessions with 759 Amplified Fragment Length Polymorphisms (AFLP) fragments. They found that 36\% were polymorphic across all genotypes. Within the group of $G$. soja accessions, $31 \%$ were polymorphic, but only $17 \%$ were polymorphic within $G$. max accessions.

Random Amplified Polymorphic DNA (RAPD) markers have been shown to be a simple and effective means to evaluate variability in crop [9] [10] [11] [12]. Based on principal component analysis of RAPD data on 35 soybean lines, Thompson et al. [13] established a core set of RAPD primers with high polymorphism in soybean. These 35 core RAPD primers have been used in other studies for genetic diversity analysis in soybean [14]. They evaluated 18 U.S. soybean ancestors and 17 selected accessions from the USDA Soybean Germplasm Collection. The clusters defined by the RAPD data corresponded to known pedigrees, origins and maturity groups.

The first demonstration of simple sequence repeat (SSR) allelic variation and heritability in a plant species was in soybean, and SSRs have been shown to be highly polymorphic in soybean [15] [16]. Brown-Guedira et al. [14] observed a higher level of genetic diversity with the SSR system compared to RAPD markers. Akkaya et al. [15] employed SSRs to evaluate the diversity of 43 ancestral and commercial cultivars representing the U.S. gene pool. They determined that, in general, SSRs with AT core motifs are most polymorphic in soybean, followed by those with ATT cores. Rongwen et al. [17] detected 11 to 26 alleles at each of seven SSR loci in a diverse sample of soybean genotypes including U.S. cultivars, and introductions of $G$. max and G. soja, including Chinese landraces. Recent studies showed that SSR markers are still widely used to assess soybean genetic diversity [18] [19].

Inter Simple Sequence Repeats (ISSR) is a different marker system that has been successfully applied to genetic analysis of plants. The ISSR method provides an alternative choice to other systems for obtaining highly reproducible markers without any necessity for prior sequence information for various genet- 
ic analyses [12] [20] [21] [22]. ISSR method takes advantage of the ubiquitously distributed SSRs in the eukaryotic genomes. Because of those abundant and rapidly evolving SSR regions, ISSR amplification has the potential of revealing larger numbers of polymorphic fragments per primer than any other marker system used such. As the PCR reaction amplify the sequence between two SSRs, the PCR products generated reveal multilocus profiles which could be revealed on agarose or polyacrylamide gels.

The objectives of the present study were to 1) assess genetic variation in soybean accessions from 11 countries using RAPD markers and 2) compare the levels of polymorphic loci generated with the RAPD and ISRR marker systems.

\section{Materials and Methods}

\subsection{Genetic Materials}

G. max varieties were provided by the Plant Gene Resources of Canada (PGRC). They were from 11 countries including Canada, China, Russia, Germany, Hungary, France, Netherlands, Sweden, South Korea, Japan, and Poland were used for the present study (Table 1). Seeds from these varieties were placed in clear Petri dishes lined with two layers of wet filter paper and kept in a growth chamber for a period of 14 to 21 days. The germination conditions consisted in a repeating cycle: 16 hours of daylight at $30^{\circ} \mathrm{C}$ and 8 hours of darkness at $20^{\circ} \mathrm{C}$. Once the seedlings reached 5 to $10 \mathrm{~cm}$, leaf samples were collected, frozen in liquid nitrogen and stored at $-80^{\circ}$ until the DNA was extracted.

Table 1. Soybean (Glycine $\max$ ) accessions used in the analysis of genetic variation.

\begin{tabular}{|c|c|}
\hline Accession and origin & Name \\
\hline \multicolumn{2}{|l|}{ Canada } \\
\hline CN33248 & Harosoy63 \\
\hline CN33251 & Harwood \\
\hline CN33259 & Capital \\
\hline CN33275 & Maple Arrow \\
\hline CN36136 & BK17_1_4 \\
\hline CN39086 & $X 702 \_3 \_2$ \\
\hline CN107377 & AC Albatros \\
\hline CN107380 & Medallion \\
\hline CN107433 & AC Hercule \\
\hline \multicolumn{2}{|l|}{ China } \\
\hline $\mathrm{CN} 29744$ & Seeh Tieh No.5 \\
\hline CN29747 & Kao Chien Tao \\
\hline CN29791 & Feng Shou No.10 \\
\hline CN29797 & Jin Shen Chi \\
\hline CN30318 & Small Golden Yello No.1 \\
\hline CN36008 & Gang 7126_9 \\
\hline $\mathrm{CN} 43603$ & Wen Feng 7 \\
\hline CN107585 & $P 1358320$ \\
\hline CN107650 & Salut216 China \\
\hline CN107658 & Hej He 3 \\
\hline
\end{tabular}




\section{Continued}

\begin{tabular}{|c|c|}
\hline \multicolumn{2}{|l|}{ France } \\
\hline $107467 \mathrm{CN}$ & Grignon 39 \\
\hline $107502 \mathrm{CN}$ & $B 10$ \\
\hline $107504 \mathrm{CN}$ & Grignon 19 \\
\hline $107507 \mathrm{CN}$ & SS \\
\hline $107509 \mathrm{CN}$ & Tulowka \\
\hline $107511 \mathrm{CN}$ & Jaune De Desme \\
\hline $10516 \mathrm{CN}$ & Rouest 13 AI2 \\
\hline $107517 \mathrm{CN}$ & SEMILUTEA \\
\hline $107518 \mathrm{CN}$ & Halton \\
\hline $107515 \mathrm{CN}$ & Geant Vert \\
\hline \multicolumn{2}{|l|}{ Germany } \\
\hline $107492 \mathrm{CN}$ & Strain No. 42 \\
\hline $107497 \mathrm{CN}$ & Strain No. 134 \\
\hline $107499 \mathrm{CN}$ & Strain No. 164 \\
\hline $107510 \mathrm{CN}$ & Bitterhof \\
\hline $107513 \mathrm{CN}$ & Nordeutsche Swart Matt \\
\hline $107548 \mathrm{CN}$ & Soja_C._St.4/58 \\
\hline $107550 \mathrm{CN}$ & Soja_C.St_. 12/58 \\
\hline $107561 \mathrm{CN}$ & Soya Heimkraft II \\
\hline $107616 \mathrm{CN}$ & Praemata Strain \\
\hline 107490 & No. 14 \\
\hline \multicolumn{2}{|l|}{ Japan } \\
\hline $107592 \mathrm{CN}$ & Karafuto No. 1 \\
\hline $107593 \mathrm{CN}$ & Kamishunbetzu \\
\hline $107595 \mathrm{CN}$ & Shinsei \\
\hline $107625 \mathrm{CN}$ & Ezonishiki \\
\hline $107629 \mathrm{CN}$ & Grignon 48 \\
\hline $107630 \mathrm{CN}$ & $($ Herb 22) \\
\hline $107631 \mathrm{CN}$ & Pulawska Wczesna \\
\hline $107632 \mathrm{CN}$ & $A 401$ \\
\hline $107634 \mathrm{CN}$ & $B 44$ \\
\hline $107635 \mathrm{CN}$ & Soja 27/60 Heimkraft I \\
\hline \multicolumn{2}{|l|}{ Hungary } \\
\hline $30629 \mathrm{CN}$ & Mica Hungara \\
\hline $32353 \mathrm{CN}$ & ISZ8 \\
\hline $107557 \mathrm{CN}$ & Keszthelyi Aproszemu Sarga \\
\hline $107559 \mathrm{CN}$ & Reatz \\
\hline $107560 \mathrm{CN}$ & Balvanska \\
\hline $107562 \mathrm{CN}$ & Vince \\
\hline $107563 \mathrm{CN}$ & Wielnska Brunatna \\
\hline $107619 \mathrm{CN}$ & PI378666 \\
\hline $107569 \mathrm{CN}$ & Iregi Nagyszemu Feher \\
\hline \multicolumn{2}{|l|}{ South Korea } \\
\hline $35309 \mathrm{CN}$ & $K A S 131 \_8$ \\
\hline $35310 \mathrm{CN}$ & KAS131_9 \\
\hline $35312 \mathrm{CN}$ & $K A S 133 \_3$ \\
\hline $35313 \mathrm{CN}$ & $P G R 7568$ \\
\hline $35319 \mathrm{CN}$ & $K A S 160 \_2$ \\
\hline $35320 \mathrm{CN}$ & $P G R 7576$ \\
\hline $35344 \mathrm{CN}$ & PGR7640 \\
\hline $35348 \mathrm{CN}$ & KAS581_13 \\
\hline $35352 \mathrm{CN}$ & PGR 7691 \\
\hline $35353 \mathrm{CN}$ & KAS604_23 \\
\hline
\end{tabular}


Continued

\begin{tabular}{|c|c|}
\hline \multicolumn{2}{|l|}{ Netherland } \\
\hline $107462 \mathrm{CN}$ & No. D.47 \\
\hline $107472 \mathrm{CN}$ & Ras 20 \\
\hline $107475 \mathrm{CN}$ & $J-5 A$ \\
\hline $107481 \mathrm{CN}$ & No.39 \\
\hline $107482 \mathrm{CN}$ & No.47 \\
\hline $107483 \mathrm{CN}$ & No.48 \\
\hline $107484 \mathrm{CN}$ & No.701 \\
\hline $107485 \mathrm{CN}$ & $N p .707$ \\
\hline $107486 \mathrm{CN}$ & No.709 \\
\hline $10487 \mathrm{CN}$ & No.713 \\
\hline \multicolumn{2}{|l|}{ Russia } \\
\hline $29403 \mathrm{CN}$ & Amurskaja \\
\hline $30391 \mathrm{CN}$ & Primorskaja \\
\hline $35917 \mathrm{CN}$ & Ussurijskaja \\
\hline $52638 \mathrm{CN}$ & Bisser \\
\hline $52641 \mathrm{CN}$ & Vzlyot \\
\hline $52644 \mathrm{CN}$ & Smena \\
\hline $52645 \mathrm{CN}$ & Seroglazka \\
\hline $107567 \mathrm{CN}$ & Salut216 \\
\hline $107572 \mathrm{CN}$ & Urozsajnaja \\
\hline \multicolumn{2}{|l|}{ Poland } \\
\hline $107547 \mathrm{CN}$ & Bydgoska 052 \\
\hline $107552 \mathrm{CN}$ & Zlotka \\
\hline $107553 \mathrm{CN}$ & N. 1954 \\
\hline $107554 \mathrm{CN}$ & N. 2054 \\
\hline $107637 \mathrm{CN}$ & Bydgoska 057 \\
\hline $107638 \mathrm{CN}$ & Bydgoska 071 \\
\hline $107639 \mathrm{CN}$ & Bydgoska 074 \\
\hline $107640 \mathrm{CN}$ & Czarna Swhn \\
\hline $107642 \mathrm{CN}$ & Zlocista \\
\hline $107643 \mathrm{CN}$ & Zolta Przebeowska \\
\hline \multicolumn{2}{|l|}{ Sweden } \\
\hline $107520 \mathrm{CN}$ & 698-1-1 \\
\hline $107525 \mathrm{CN}$ & $744-1$ \\
\hline $107526 \mathrm{CN}$ & $748-5$ \\
\hline $107529 \mathrm{CN}$ & $749-2$ \\
\hline $107533 \mathrm{CN}$ & $753-1$ \\
\hline $107534 \mathrm{CN}$ & $634-13-42-2$ \\
\hline $107535 \mathrm{CN}$ & $634-20-4-29$ \\
\hline $107536 \mathrm{CN}$ & 706-4-1 \\
\hline $107537 \mathrm{CN}$ & $756-2$ \\
\hline $107541 \mathrm{CN}$ & $770-3$ \\
\hline
\end{tabular}

\subsection{DNA Extraction and Amplification}

Total DNA was extracted from fresh frozen leaf material using the CTAB extraction protocol as described by Boyd et al. [23] and Moraefi et al. [22]. After extraction, DNA was stored in a freezer at $-20^{\circ} \mathrm{C}$.

Twelve RAPD primers were chosen for preliminary amplification of DNA 
from 108 G. $\max$ varieties. Five of these primers were selected for this genetic variation investigation (Table 2). To compare RAPD and ISSR markers systems, five ISSR primers that were previously evaluated were also used for DNA amplification [24]. They are described in Table 2. All primers were standardized to a $25 \mathrm{ng} / \mathrm{ml}$ stock solution. DNA amplification was performed using the procedure described by Nkongolo et al. [20] and Boyd et al. [23]. PCR (Polymerase Chain Reaction amplification) amplification was performed in a $25 \mu \mathrm{l}$ volumes that contained $4 \mathrm{mM} \mathrm{MgCl}_{2}, 2.1 \mu \mathrm{l}$ of 10x buffer (BioBasics), $200 \mu \mathrm{M}$ of each dNTP (BioBasics), $0.5 \mu \mathrm{M}$ primers, $10 \mathrm{ng}$ of template and 0.625 units of Taq polymerase (BioBasics). A negative control was included with every reaction. The samples were overlaid with mineral oil and were amplified on an Eppendorf Master Cycler thermal cycler. The thermal cycler was programmed for a "hot start" of 5 minutes at $95^{\circ} \mathrm{C}$ followed by 2 minutes at $85^{\circ} \mathrm{C}$ and 42 cycles of 30 secs at $95^{\circ} \mathrm{C}$, 1:30 min at $55^{\circ} \mathrm{C}$ and 30 secs at $72^{\circ} \mathrm{C}, 7$ minutes extension at $72^{\circ} \mathrm{C}$.

The amplified DNA was separated using a $2 \%$ agarose gel in $0.5 \mathrm{X}$ TrisBorate-EDTA buffer (TBE) containing $0.5 \mu \mathrm{g} / \mathrm{ml}$ ethidium bromide. The gels were documented using a Bio-Rad Chemidoc XRS system and analyzed with Discovery Series Quantity One 1D Analysis Software.

\subsection{ISSR and RAPD Analysis}

ISSR and RAPD primers that amplified consistent profiles across the populations were selected for the final analysis. ISSR and RAPD amplification products from each accession from the eleven countries were scored using POPGENE version 1.32 [17]. The presence or absence of fragments was scored as 1 or 0 for each band, in order to determine variation between accessions (within and between countries). Genetic distances were generated using FreeTree [25] [26].

Table 2. Polymorphic loci (\%) generated with RAPD primers using soybean accessions from different countries.

\begin{tabular}{ccc}
\hline Countries & Total number of polymorphic bands & Polymorphic bands (\%) \\
\hline Canada & 58 & $29.90 \%$ \\
China & 48 & $24.74 \%$ \\
France & 93 & $47.94 \%$ \\
Germany & 69 & $35.57 \%$ \\
Japan & 67 & $34.54 \%$ \\
Hungary & 84 & $43.30 \%$ \\
South Korea & 66 & $34.02 \%$ \\
Netherlands & 51 & $26.29 \%$ \\
Russia & 77 & $39.69 \%$ \\
Poland & 72 & $37.11 \%$ \\
Sweden & 62 & $31.96 \%$ \\
\hline
\end{tabular}




\section{Results}

\section{RAPD Analysis}

All DNA samples were tested to assess their quality. They all showed a large molecular weight band, indicating that they were not degraded and were deemed suitable for PCR amplification. A total of 12 RAPD primers were screened. Five primers were selected for further study based on their amplification and reproducibility to analyze the DNA samples from all the targeted countries. These primers include OPA 11, Pinus 23, UBC 377, UBC186, and Grasse 8 (Table 3).

Figure 1 and Figure 2 depict amplified products generated with RAPD primers OPA 11 and UBC 377. The highest polymorphic index among accessions was $48.00 \%$ in France, followed by accessions from Hungary with $43.30 \%$. Over all, the lowest polymorphic index was $29.90 \%, 26.29 \%$ and $24.74 \%$ observed in accessions from Canada, Netherlands and China, respectively (Table 4).

At the primer level, primers RAPD 186 and RAPD Grass 8 generated the most number of bands (41) followed by UBC 377 with 40 bands. The lowest number of amplified product was observed with primer Pinus 23. The highest level of polymorphic loci (46.30\%) was detected with primer RAPD 186 and the lowest with UBC 377 (Table 4). Overall, there were no significant differences among primers for the detection of polymorphism using all G. max accessions.

The genetic distance values based on RAPD data are described in Table 5. Accessions from Canada and Netherland were the most genetically closely related with accessions from Russia and South Korea being the most distant (Table 5). Overall, RAPD data revealed that the accessions from different countries are closely related with $64 \%$ genetic distance values below 0.40 . Comparison of ISSR and RAPD Polymorphism.

Table 3. Nucleotide sequence and G+C content for the five ISSR and RAPD primers used to amplify DNA accessions.

\begin{tabular}{ccc}
\hline Primer identification & Nucleotide sequence (5'-3') & G+C content (\%) \\
\hline RAPD primers & GTGCGTGGCT & 70 \\
RAPD UBC 186 & TCCCGAACCG & 70 \\
UBC 337 & GGGTAACGCC & 70 \\
GRASSE 8 & CCCGCCTTCC & 80 \\
PINUS 23 & ACGACGACGACGGAC & 64.28 \\
ISSR primers & ACTCACTCGC & 60 \\
ISSR 5 & GACAGACAGACAGACA & 50.00 \\
ISSR Echt 6 & TTGTTGTTGTTGTTGGB & 35.3 \\
UBC 873 & GTGTGTGTGTGTGTGTYA & 44.44 \\
SC ISSR 6 & . & \\
ISSR 849 &
\end{tabular}


Table 4. Polymorphic loci (\%) generated by each RAPD primer used to amplify DNA from soybean (Glycine max) accessions from different countries.

\begin{tabular}{|c|c|c|c|c|c|c|c|c|c|c|c|c|}
\hline \multicolumn{13}{|c|}{ Countries } \\
\hline Primers & Canada & China & France & Germany & Japan & Hungary & $\begin{array}{l}\text { South } \\
\text { Korea }\end{array}$ & Netherlands & Russia & Poland & Sweden & $\begin{array}{c}\text { Polymorphic } \\
\text { bands (\%) }\end{array}$ \\
\hline $\begin{array}{c}\text { RAPD UBC } \\
186\end{array}$ & $10 / 41$ & $14 / 41$ & $19 / 41$ & $19 / 41$ & $19 / 41$ & $25 / 41$ & $20 / 41$ & $20 / 41$ & $21 / 41$ & $24 / 41$ & $18 / 41$ & $46.34 \%$ \\
\hline $\begin{array}{c}\text { RAPD UBC } \\
377\end{array}$ & $13 / 40$ & $8 / 40$ & $21 / 40$ & $13 / 40$ & $18 / 40$ & $14 / 40$ & $14 / 40$ & $11 / 40$ & $15 / 40$ & $20 / 40$ & $16 / 40$ & $41.28 \%$ \\
\hline RAPD Grasse8 & $14 / 41$ & $/ 1841$ & $21 / 41$ & $18 / 41$ & $17 / 41$ & $20 / 41$ & $17 / 41$ & $16 / 41$ & $18 / 41$ & $16 / 41$ & $19 / 41$ & $43.02 \%$ \\
\hline OPA11 & $18 / 38$ & $16 / 38$ & $22 / 38$ & $20 / 38$ & $18 / 38$ & $18 / 38$ & $16 / 38$ & $9 / 38$ & $21 / 38$ & $16 / 38$ & $14 / 38$ & $44.98 \%$ \\
\hline PINUS 23 & $22 / 34$ & $13 / 34$ & $17 / 34$ & $13 / 34$ & $14 / 34$ & $18 / 34$ & $14 / 34$ & $13 / 34$ & $14 / 34$ & $14 / 34$ & $12 / 34$ & $43.85 \%$ \\
\hline
\end{tabular}

Table 5. Distance matrix generated with Glycine max RAPD data (FreeTree).

\begin{tabular}{|c|c|c|c|c|c|c|c|c|c|c|c|}
\hline \multicolumn{12}{|c|}{ Countries } \\
\hline & Canada & China & France & Germany & Japan & Hungary & South Korea & Netherlands & Russia & Poland & Sweden \\
\hline China & & 0.00000 & 0.43220 & 0.43396 & 0.38393 & 0.36667 & 0.34677 & 0.23214 & 0.29323 & 0.27200 & 0.23333 \\
\hline France & & & 0.00000 & 0.51240 & 0.43077 & 0.42336 & 0.43478 & 0.26119 & 0.39041 & 0.31034 & 0.31618 \\
\hline Germany & & & & 0.00000 & 0.40833 & 0.41270 & 0.38168 & 0.25620 & 0.34783 & 0.30075 & 0.28571 \\
\hline Japan & & & & & 0.00000 & 0.52101 & 0.38346 & 0.29167 & 0.35000 & 0.34351 & 0.30952 \\
\hline Hungary & & & & & & 0.00000 & 0.41912 & 0.35537 & 0.42446 & 0.38060 & 0.32824 \\
\hline South Korea & & & & & & & 0.00000 & 0.41525 & 0.55814 & 0.43511 & 0.31111 \\
\hline Netherlands & & & & & & & & 0.00000 & 0.47009 & 0.45872 & 0.37037 \\
\hline Russia & & & & & & & & & 0.00000 & 0.50781 & 0.38931 \\
\hline Poland & & & & & & & & & & 0.00000 & 0.45690 \\
\hline Sweden & & & & & & & & & & & 0.00000 \\
\hline
\end{tabular}

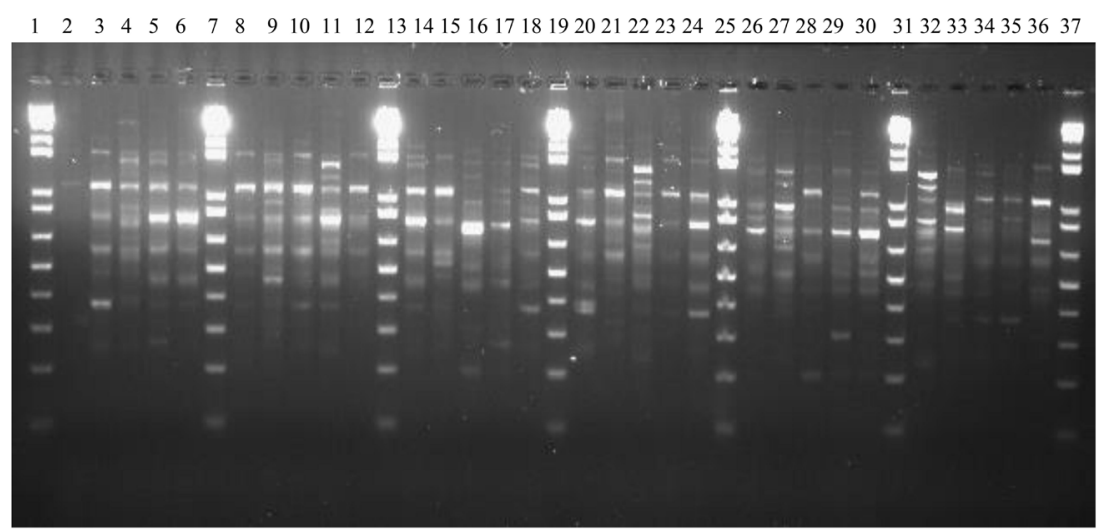

Figure 1. RAPD amplification of Soybean (Glycine max) accessions with primer RAPD OPA 11. Lanes $1,7,13,19,25,31$ and 37 contains $1 \mathrm{~Kb}^{+}$DNA ladder. Lanes 2 to 10 represents accessions from Canada; lanes 8 to 12 contain accessions from China; lanes 14 to 18 contain accessions from France; lanes 20 to 24 contain accessions from Germany; lanes 26 to 30 contain accessions from Japan and lanes 32 to 36 contain accessions from Hungary. 


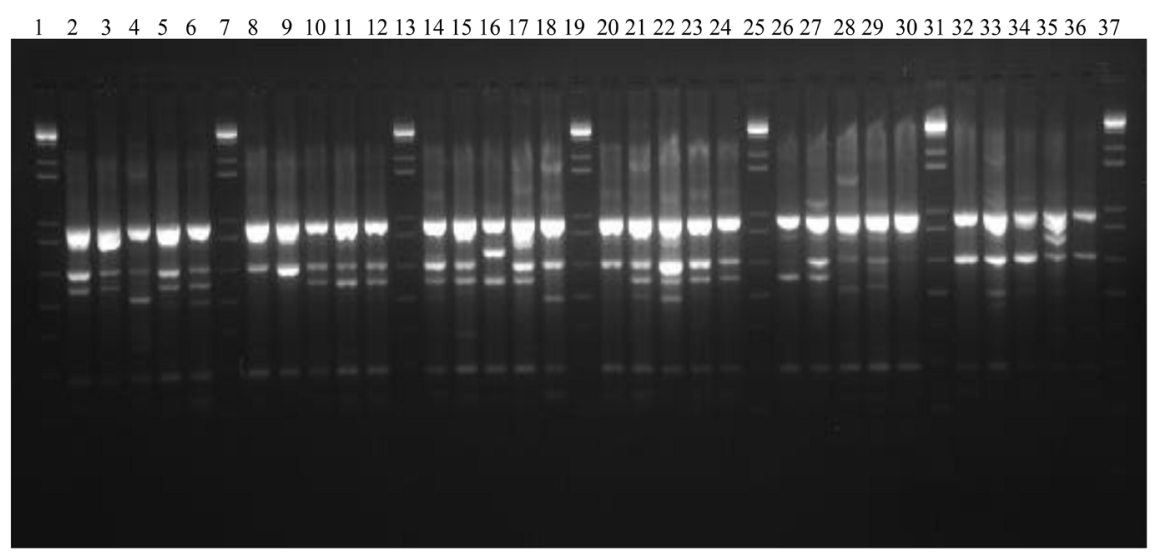

Figure 2. RAPD amplification of Soybean (Glycine max) accessions with primer UBC 377. Lanes $1,7,13,19,25,31$ and 37 contains $1 \mathrm{~Kb}^{+}$DNA ladder. Lanes 2 to 6 represents accessions from Canada; lanes 8 to 12 contain accessions from China; lanes 14 to 18 contain accessions from France; lanes 20 to 24 contain accessions from Germany; lanes 26 to 30 contain accessions from Japan and lanes 32 to 36 contain accessions from Hungar.

Detailed analysis of ISSR analysis generated with the same primer used in this study has been described elsewhere. For the present study, the level of polymorphism generated with ISSR and RAPD primers were compared. Data are summarized in figure 19 and 20. Overall, with the exception of data with Chinese accessions, they were no significant difference between ISSR and RAPD polymorphism data (Figure 3). This was confirmed when the accessions from all the countries were combined to compare ISSR and RAPD data (Figure 4).

\section{Discussion}

Assessment of genetic diversity in a crop species is a prerequisite to its improvement and helps to generate genetically diversified breeding populations. Considerable variation has been recorded for morphological, physiological and agronomic traits in G. $\max$ crops [12].

The average level of genetic variation detected with the five RAPD primers was 35\%. This level of polymorphism is lower than other studies [11] [14].

Overall, ISSR and RAPD primers used in the present study revealed a similar level of polymorphism for the G. max accessions analyzed. Previous studies have shown different levels of polymorphism within and among different varieties and species when RAPD and ISSR were compared. For example, Fang and Roose [27] reported high levels of interspecific variation with RAPD markers than with ISSR markers in Citrus species. On the other hands, several authors detected high level of polymorphism with ISSR system compared to RAPD in several plants [12] [20] [28] [29] [30]. Moreover, a close look of the genetic distance analyses in the present study revealed the accessions from different countries are closely related with $64 \%$ genetic distance values below 0.40 while ISSR data showed the opposite with $82 \%$ of genetic distance values among accessions above 0.40 [24]. 


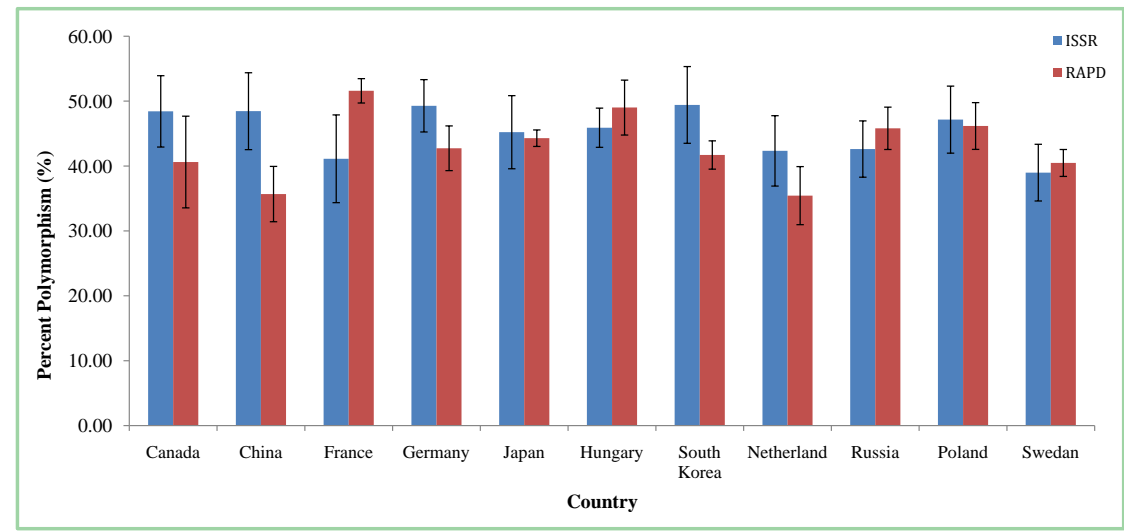

Figure 3. Level of polymorphism generated with ISSR and RAPD primers using soybean (Glycine $\max$ ) accessions per country. No significant difference between RAPD and ISSR for each pool.

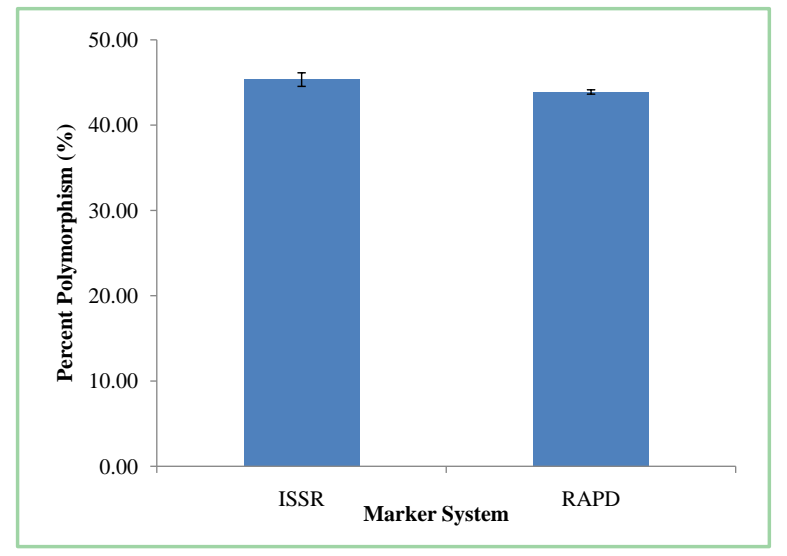

Figure 4. Level of polymorphism generated with ISSR and RAPD primers based on amplification of soybean (Glycine max) accessions from different countries. No significant difference between RAPD and ISSR.

Technically, RAPD and ISSR are both dominant markers that target different areas in the genome. RAPD markers reveal polymorphisms in coding and non-coding regions, as well as repeated or single copy sequences covering the entire genome [31]. The system involves the use of a single oligonucleotide of arbitrary sequence to prime the amplification of template DNA by PCR. An oligonucleotide will prime amplification from a genomic template if the binding site on the opposite strand of the template exists within a distance, which can be traversed by the DNA polymerase (up to several thousand nucleotides).

The amplification with arbitrary primers is mainly driven by the interaction between primer, template annealing sites and enzymes [20] [32]. Genomic polymorphisms at one or both priming sites result in the non-amplification of a band. RAPD are thus dominant markers and appearance of a band implies homology with the primer used. All other alleles at the priming site will be represented by absence of the band. Dominant RAPD markers resulting from insertions or deletions between priming sites and observed as different sized fragments amplified from the same locus, are detected rarely (Williams et al., 
1990). A primer usually amplifies several bands, each originating from a different genomic location. The nature of the fragments amplified is influenced dramatically by the sequence of both primers and template.

RAPD usually uses a $10 \mathrm{bp}$ arbitrary primer. Although the sequences are arbitrary chosen, two basic criteria must be met: at least 50\% Guanine-Cytosine content and the absence of palindromic sequences [32]. Primers as short as 5 nucleotides give more complex banding patterns requiring more sophisticated electrophoretic and staining procedures (acrylamide gels and silver staining). RAPD analysis results in the amplification of one locus and two kinds of polymorphism: the band may be present or absent, and the brightness of the band may be different. Band intensity differences could be due to low copy number or relative sequence abundance (Devos and Gale [33] and may serve to distinguish homozygote dominant individuals from heterozygotes, as less bright bands are expected for the latter. Ellsworth et al. [34] indicated that the fact that fainter bands are generally robust, varying degrees of primer mismatch may account for band intensity differences. As the source of the band intensity difference is uncertain most studies disregard scoring differences in band intensity [32].

The origin of the ISSR amplification products is known to be from the sequences between two simple-sequence repeat (also known as Microsatellite) primer sites where length variation does not necessarily reflect simple-sequence length polymorphism [35]. Microsatellite loci are dispersed throughout the genome and are hypervariable because of DNA slippage (Semagn et al., 2006). ISSR marker system accesses variation in the numerous micro-satellite regions dispersed throughout the genome (Semagn et al., 2006) and circumvents the challenge of characterizing individual loci that other molecular approaches require. ISSR involves amplification of regions between adjacent, inversely oriented microsatellites, using a simple sequence repeat (SSR) motif containing primers anchored at $3^{\prime}$ or $5^{\prime}$ end by two or four arbitrary, often degenerate nucleotides [35]. Microsatellites are very short (usually 10 - $20 \mathrm{bp}$ ) stretches of DNA that are hypervariable, expressed as different variants within populations and among different species. They are characterized by mono-, di- or tri-nucleotide repeats (AA, AG, CAG respectively) that have $4-10$ units side by side. ISSR marker system is based on the use of $15-20$ bp primers designed to be complementary to microsatellite sequences found throughout Eukaryotic genomes. Therefore, this PCR based technique involves the amplification of DNA segments present between two identical microsatellites that are oriented in opposite directions [36]. ISSRs specifically target the di- and tri-nucleotide repeats a type of microsatellite that is characteristic of the nuclear genome (mono nucleotide are found in chloroplast genome [37].

Most often ISSR detects more polymorphisms than RAPD primers because of the high levels of variability in microsatellite loci. The discrepancy between variations revealed by RAPD and ISSR result from different targeted genomic areas, which undergo a different evolutionary process due to selection forces [12] [31] 
[38]. Different genetic information is generated when RAPD and ISSR molecular marker techniques are used to assess the inter-specific and intra-specific variability. The level of variation detected with each system greatly depends on the primer used therefore making comparisons for the levels of polymorphism generated with ISSR and RAPD marker systems inappropriate. In addition, both markers systems are cost efficient being PCR based with results from ISSR analyses more repeatable from lab to lab due to longer primers used compared to RAPD [20] [22] [23].

Among other molecular marker systems, microsatellites and AFLP have been widely used to assess genetic diversity among and within populations [3] [38] [39]. Microsatellites amplification is expected to produce a single marker since the microsatellite primers target a single locus [3]. This means that many reactions would be needed to properly determine a population's genetic variability. AFLP has been gaining popularity over microsatellites in these types of studies. This is in part because AFLP assay is equivalent to the amplification of several microsatellite primers [40]. But, ISSR and RAPD primers are easier to use than AFLP and microsatellites [29] [40] [41].

\section{Conclusion}

The main objectives of the present study were to 1) assess the level of genetic variation among 108 soybean accessions from different countries using RAPD markers and 2) compare ISSR and RAPD marker systems in detecting polymorphic loci in soybeans. The average level of polymorphic loci detected with the RAPD primers was 35\%. Overall, RAPD data revealed that the accessions from different countries are closely related with $64 \%$ genetic distance values below 0.40 . The levels of polymorphism detected with the RAPD and ISSR marker systems were moderate and similar even if they target different region of the soybean genome. A combination of different marker systems that include RAPD/ISSR, SSR, and SNPs should provide the most accurate information on genetic variation of soybean accessions.

\section{Acknowledgements}

Financial support from Laurentian University through the Research Fund to Faculty (LURF) is greatly appreciated. Thanks to the Saudi Arabia Government for a graduate scholarship to Sarah Alamri.

\section{Conflicts of Interest}

The authors declare no conflicts of interest regarding the publication of this paper.

\section{References}

[1] Ford, B.A., Ball, P. W. and Ritland K. (1991) Allozyme Diversity and Genetic Relationships among North American Members of the Short-Beaked Taxa of Carex sect. 
Vesicariae (Cyperaceae). Systematic Botany, 16, 116-131. https://doi.org/10.2307/2418977

[2] Lu, H., Li, J.S., Liu, J.L. and Bernardo, R. (2002) Allozyme Polymorphisms of Maize Populations from Southwestern China. Theoretical and Applied Genetics 104, 119-126. https://doi.org/10.1007/s001220200014

[3] Prasad, M., Varshney, R.K., Roy, J.K., Balyan, H.S. and Gupta, P.K. (2000) The Use of Microsatellites for Detecting DNA Polymorphism, Genotype Identification and Genetic Diversity in Wheat. Theoretical and Applied Genetics, 100, 584-592. https://doi.org/10.1007/s001220050077

[4] Apuya, N., Frazier, B.L., Keim, P.E., Roth, J. and Lark, K.G. (1988) Restriction Length Polymorphisms as Genetic Markers in Soybean, Glycine max (L.) Merrill. Theoretical and Applied Genetics, 75, 889-901. https://doi.org/10.1007/BF00258050

[5] Keim, P., Shoemaker, R.C. and Palmer, R.G. (1989) RFLP Diversity in Soybean. Theoretical and Applied Genetics, 77, 786-792. https://doi.org/10.1007/BF00268327

[6] Keim, P., Diers, B.W., Olson, T.C. and Shoemaker, R.C. (1990) RFLP Mapping in Soybean: Association between Marker Loci and Variation in Quantitative Traits. Genetics, 126, 735-742.

[7] Keim, P., Beavis, W., Schupp, J., et al. (1992) Evaluation of Soybean RFLP Marker Diversity in Adapted Germ Plasm. Theoretical and Applied Genetics, 85, 205-212. https://doi.org/10.1007/BF00222861

[8] Maughan, P.J., Saghai Maroof, M.A., Buss, G.R., et al. (1996) Amplified Fragment Length Polymorphism (AFLP) in Soybean: Species Diversity, Inheritance, and Near-Isogenic Line Analysis. Theoretical and Applied Genetics, 93, 392-401. https://doi.org/10.1007/BF00223181

[9] Li, Z. and Nelson, R.L. (2002) RAPD Marker Diversity among Soybean and Wild Soybean Accessions from Four Chinese Provinces. Crop Science, 42, 1737-1744. https://doi.org/10.2135/cropsci2002.1737

[10] Devaiah, K., Balusubramani, S.P. and Venkatasubramanian, P. (2010) Development of Randomly Amplified Polymorphic DNA Based SCAR Marker for Identification of Ipomoea mauritiana Jacq (Convolvulaceae). Evidence-Based Complementary and Alternative Medicine, 2010, Article ID: 868720. https://doi.org/10.1093/ecam/neq023

[11] Khan, F., Hakeem, K.R., Siddiqi, T.O., et al. (2013) RAPD Markers Associated with Salt Tolerance in Soybean Genotypes Under Salt Stress. Applied Biochemistry and Biotechnology, 170, 257-272. https://doi.org/10.1007/s12010-013-0182-6

[12] Costa, R., Pereira, G., Garrido, I., Tavares-De-Sousa, M.M. and Espinosa, F. (2016) Comparison of RAPD, ISSR, and AFLP Molecular Markers to Reveal and Classify Orchardgrass (Dactylis glomerata L.) Germplasm Variations. PLoS ONE, 11, e0152972. https://doi.org/10.1371/journal.pone.0152972

[13] Thompson, J.A., Nelson, R.L. and Vodkin, L.O. (1998) Identification of Diverse Soybean Germplasm Using RAPD Markers. Crop Science, 38, 1348-1355. https://doi.org/10.2135/cropsci1998.0011183X003800050033x

[14] Brown-Guedira, G.L., Thompson, J.A., Nelson, R.L. and Warburton, M.L. (2000) Evaluation of Genetic Diversity of Soybean Introductions and North American Ancestors Using RAPD and SSR Markers. Crop Science, 40, 815-823. https://doi.org/10.2135/cropsci2000.403815x

[15] Akkaya, M.S., Bhagwat, A.A. and Cregan, P.B. (1992) Length Polymorphism of Simple Sequence Repeat DNA in Soybean. Genetics, 47, 1131-1139. 
[16] Diwan, N. and Cregan, P.B. (1997) Automated Sizing of Fluorescent-Labeled Simple Sequence Repeat (SSR) Markers to Assay Genetic Variation in Soybean. Theoretical and Applied Genetics, 95, 723-733. https://doi.org/10.1007/s001220050618

[17] Rongwen, J., Akkaya, M.S., Lavi, U. and Cregan, P.B. (1995) The Use of Micro Satellite DNA Markers for Soybean Genotype Identification. Theoretical and Applied Genetics, 90, 43-48. https://doi.org/10.1007/BF00220994

[18] Kachare S., Tiwari, S., Tripathi, N., et al. (2020) Assessment of Genetic Diversity of Soybean (Glycine max) Genotypes Using Qualitative Traits and Microsatellite Markers. Agricultural Research, 9, 23-34. https://doi.org/10.1007/s40003-019-00412-y

[19] Vieira, M.L.C., Santini, L., Diniz, A.L. and Munhoz, C.F. (2016) Microsatellite Markers: What They Mean and Why They Are So Useful. Genetics and Molecular Research, 39, 312-328. https://doi.org/10.1590/1678-4685-GMB-2016-0027

[20] Nkongolo, K.K., Michael, P. and Demers, T. (2005) Application of ISSR, RAPD, and Cytological Markers to the Certification of Picea mariana, $P$. glauca, and P. engelmannii Trees, and Their Putative Hybrids. Genome, 48, 302-311.

https://doi.org/10.1139/g04-118

[21] Mudibu J., Nkongolo, K.K.C., Mehes-Smith, M. and Kalonji Mbuyi, A. (2011) Genetic Analysis of a Soybean Genetic Pool Using ISSR Marker: Effect of Gamma Radiation on Genetic Variability. International Journal of Plant Breeding and Genetics, 5, 235-245. https://doi.org/10.3923/ijpbg.2011.235.245

[22] Moarefi, N, Michael, P., Beckett, P. and Nkongolo, K.K. (2018) Identification of Molecular Markers Differentiating Betula papyrifera and B. pumila Populations from Northern Ontario (Canada). American Journal of Environmental Sciences, 14, 246-256. https://doi.org/10.3844/ajessp.2018.246.256

[23] Boyd, M., Panoyan, M.A., Michael, P. and Nkongolo, K.K. (2019) Development and Characterization of Species-Diagnostic ISSR and SCAR DNA Markers Differentiating Red Maple (Acer rubrum) and Silver Maple (A. saccharinum). Genome, 62, 527-535. https://doi.org/10.1139/gen-2019-0037

[24] Alamri, S. (2014) Comparative Analysis of Soybean (Glycine max) Accessions Using Inter Simple Sequence Repeat (ISSR) and Random Amplified Polymorphic DNA (RAPD) Markers. M.Sc. Thesis, Laurentian University, Sudbury, Ontario, 106 p. https://zone.biblio.laurentian.ca/handle/10219/2201

[25] Yeh, F.C. and Boyle, T.J.B. (1997) Population Genetic Analysis of Co-Dominant and Dominant Markers and Quantitative Traits. Belgian Journal of Botany, 129, 157.

[26] Pavlicek, A., Hrda, S. and Flegr, J. (1999) Freetree-Freeware Program for Construction of Phylogenetic Trees on the Basis of Distance Data and Bootstrap/Jackknife Analysis of the Tree Robustness. Folia Biologica, 5, 97-99.

[27] Fang, D.Q. and Roose, M.L. (1997) Identification of Closely Related Citrus Cultivars with Inter-Simple Sequence Repeat Markers. Theoretical and Applied Genetics, 95, 408-417. https://doi.org/10.1007/s001220050577

[28] Rus-Kortekaas W., Smulders, M.J.M., Arens, P. and Vosman, B. (1994) Direct Comparison of Levels of Genetic Variation in Tomato Detected by a GACA-Containing Microsatellite Probe and by Random Amplified Polymorphic DNA. Genome, 37, 375-381. https://doi.org/10.1139/g94-053

[29] Nagaoka, T. and Ogihara, Y. (1997) Applicability of Inter-Simple Sequence Repeat Polymorphisms in Wheat for Use as DNA Markers in Comparison to RFLP and RAPD Markers. Theoretical and Applied Genetics, 94, 597-602. https://doi.org/10.1007/s001220050456 
[30] Raina S.N., Rani, V., Kojima, T., Ogihara, Y., Singh, K.P. and Devarumath, R.M. (2001) RAPD and ISSR Fingerprints as Useful Genetic Markers for Analysis of Genetic Diversity, Varietal Identification, and Phylogenetic Relationships in Peanut (Arachis hypogaea) Cultivars and Wild Species. Genome, 44, 763-772. https://doi.org/10.1139/g01-064

[31] Williams, J.G.K., Kubelik, A.R., Livak, K.J., Rafalski, J.A. and Tingey, S.V. (1990) DNA Polymorphisms Amplified by Arbitrary Primers Are Useful as Genetic Markers. Nucleic Acids Research, 18, 6531-6535. https://doi.org/10.1093/nar/18.22.6531

[32] Semagn K., Bjornstad, A. and Ndjiondjop, M.N. (2006) An Overview of Molecular Markers Methods for Plants. African Journal of Biotechnology, 5, 2540-2568.

[33] Devos, K.M. and Gale, M.D. (1992) The Use of Random Amplified Polymorphic DNA Markers in Wheat. Theoretical and Applied Genetics, 84, 567-572. https://doi.org/10.1007/BF00224153

[34] Ellsworth, D.L., Rittenhouse, D. and Honeycutt, R.L. (1993) Artifactual Variation in Random Amplified Polymorphic DNA Banding Patterns. BioTechniques, 14, 214-217.

[35] Zietkiewicz, E., Rafalski, A. and Labuda, D. (1994) Genome Fingerprinting by Simple Sequence Repeat (SSR)-Anchored Polymerase Chain Reaction Amplification. Genomics, 20, 176-183. https://doi.org/10.1006/geno.1994.1151

[36] Reddy, P.M., Sarla, N. and Siddiq, E.A. (2002) Inter Simplesequence Repeat (ISSR) Polymophism and Its Application in Plant Breeding. Euphytica, 128, 9-17. https://doi.org/10.1023/A:1020691618797

[37] Queller, D.C., Strassmann, J.E. and Hughes, C.R. (1993) Microsatellites and Kinship. Trends in Ecology \& Evolution, 8, 285-288. https://doi.org/10.1016/0169-5347(93)90256-O

[38] Verma, K.S., Ul Haq, S., Kachhwaha, S. and Kothari, S.L. (2017) RAPD and ISSR Marker Assessment of Genetic Diversity in Citrullus colocynthis (L.) Schrad: A Unique Source of Germplasm Highly Adapted to Drought and High-Temperature Stress. 3 Biotech, 7, Article No. 288.

[39] Hao, C.Y., Wang, L.F., Zhang, X.Y., You, G.X., Dong, Y.S., Jia, J.Z., Liu, X.W., Shang, X.W., Liu, S.C. and Cao, Y.S. (2006) Genetic Diversity in Chinese Modern Wheat Varieties Revealed by Microsatellite Markers. Science in China Series C, 49, 218-226. https://doi.org/10.1007/s11427-006-0218-Z

[40] Roy, J.K., Lakshmikumaran, M.S., Balyan, H.S. and Gupta, P.K. (2004) AFLP-Based Genetic Diversity and Its Comparison with Diversity Based on SSR, SAMPL, and Phenotypic Traits in Bread Wheat. Biochemical Genetics, 42, 43-89. https://doi.org/10.1023/B:BIGI.0000012143.48298.71

[41] Mattioni, C., Casasoli, M., Gonzalez, M. and Ipinza, R. (2002) Comparison of ISSR and RAPD Markers to Characterize Three Chilean Nothofagus Variety. Theoretical and Applied Genetics, 104, 1064-1070. https://doi.org/10.1007/s00122-001-0824-x 